\section{JTS}

http://penerbit.uthm.edu.my/ojs/index.php/jts ISSN : 2229-8940 e-ISSN : 2600-7940
Journal of Techno

Social

\title{
The Challenges of the Fight Against Insurgency in Northeastern Nigeria
}

\section{${ }^{1}$ Babayo Sule ${ }^{2}$, Abdulkadir Ahmed ${ }^{3}$, Abubakar Umar Alhaji ${ }^{4}$, Muhammad Aminu Yahaya ${ }^{5}$, Kabir Isah Gambarawa}

1,2,3 Department of Political Science, Faculty of Humanities Management and Social Sciences, Federal University Kashere Gombe, Gombe State, NIGERIA

${ }^{4}$ Department of Public Administration, Faculty of Arts and Social Sciences,

Gombe State University, NIGERIA

${ }^{5}$ Department of General Studies, Yusuf Bala Usman College of Legal and General Studies,

Daura Katsina State, NIGERIA

*Corresponding author

DOI: https://doi.org/10.30880/jts.2018.11.01.002

Received 00 Month 2000; Accepted 01 Month 2000; Available online 30th June 2019

\begin{abstract}
The Boko Haram insurgency in Northeastern Nigeria has been one of the most devastating phenomena in the country claiming thousands of lives and properties worth billions of Naira in the process. All the governmental efforts put in place so far failed to curb the menace as the threat of insurgency continues in some parts of Northeastern Nigeria. This work examined the major challenges that are responsible for the continuation of insurgency despite divergent measures taken by the government to address the problem. The research used both primary and secondary sources of data. The primary source is the in-depth interview conducted with some selected informants who are related with security issues involving security personnel in the Northeast, policy-makers, analysts, some repented insurgents and media men. The secondary source is the use of the existing documents such as books, reports, news and internet sources. The data obtained was discussed and analysed using thematic analytical interpretations to arrive at findings. The research discovered that, the major reasons or challenges that made insurgency defiant of all solutions in Northeastern Nigeria consists of corruption, conspiracy, inappropriate approach, lack of proper intelligence, hostility from the host communities, nature of Nigerian borders, politicisation of security issues, religious dogmatism and lack of cooperation among the security personnel. Therefore, for an effective approach towards addressing the problem of insurgency in Northeastern Nigeria, the paper recommends that a multi-dimensional approach is required such as religious censorship, intelligence, cooperation, prudence and good governance.
\end{abstract}

Keywords: insurgency, Northeastern Nigeria, challenges, Boko Haram, threats, security

\section{Introduction}

The phenomenon of Boko Haram insurgency in Northeastern Nigeria and other parts of the country has turned the country into one of the insecured states in Sub-Saharan Africa and in the world at large. The issue which started in form of a radical preaching in 2009 led to a violent clash between the Boko Haram sect and the security agencies in Borno, a Northeastern state which heralded the formation of an insurgent group that later metamorphosed into a violent terror 
group (De Montclos, 2014). The nature of leadership and followership in the country entrenched a deep-rooted corruption of all magnitude leading to an extreme poverty with about $70 \%$ of the population living in absolute poverty and more than $50 \%$ of the youth are unemployed (National Bureau of Statistics, 2017).

The socioeconomic situation in the country created a vulnerable prey of youth who were idle and readily available for criminal activities to be incorporated in the activities of Boko Haram. Within a short period of a time between 20092012, the insurgents enlarged in number and their weapons and logistics became sophisticated to the extent that the entire Northeastern Nigeria was bedeviled with insurgents' activities. More than sixteen (16) local governments in Adamawa, Borno and Yobe became a territory under the control of the Boko Haram insurgents (El Kaim, 2012). The Boko Haram insurgency claimed thousands of lives estimated as at 2018 to be approximately 22, 000 and properties worth billions of Naira were destroyed. The insurgents compelled many inhabitants in the Northeastern Nigeria to embark on migration leading to the establishment of Internally Displaced Persons (IDPs), agricultural activities were halted for several years thereby creating food insecurity in the region and in the entire country, commercial activities in the Lake Chad were blocked and educational activities were stopped for many years in the most affected areas (Harvard Divinity Project, 2018).

There are many measures put in place by the Nigerian government to curtail the activities of insurgents in the Northeast and other parts of the country but, the insurgency continued unabated from 2012 to 2014 and it even escalated in to bombings of churches and mosques, markets, stations, security outfits, public gathering and other related places (De Montclos, 2014). This is one of the factors that are believed to have prolonged the insurgency from 2009 to date. There are many other challenges that impede the success of the fight against insurgency in Northeastern Nigeria which require a thorough and scientific investigation if the phenomenon is to be contained totally.

This study is a critical examination and analysis of the challenges that are encountered in the fight against insurgency in Northeastern Nigeria particularly those serious challenges that denied the governmental security agencies from arresting the Boko Haram attacks and grounded the insurgency to its logical conclusion.

\section{Literature Review}

The literature review is conducted using thematic approach in which scholastic views were critically reviewed to enable for the identification of the research gap and contribution to knowledge. The literature is reviewed according to the following issues: background of the area of study, Boko Haram insurgency in Northeastern Nigeria, genesis of Boko Haram insurgency in Northeastern Nigeria, causes of Boko Haram insurgency in Northeastern Nigeria, impacts of Boko Haram insurgency in Northeastern in Nigeria and the response of the Nigerian government and the international community.

\section{1 Background of the Area of Study}

The area of study in this work is the Northeastern Nigeria. Northeast is one of the six geo-political zones recognised in the Nigerian 1999 Constitution. The zone consists of six states including Adamawa, Bauchi, Borno, Gombe, Taraba and Yobe. This zone is presented below in a map of Nigeria for a better perception. The Northeastern states are marked with red colour in the map.

Figure 1: Map of Nigeria Showing the Northeast Geopolitical Zone

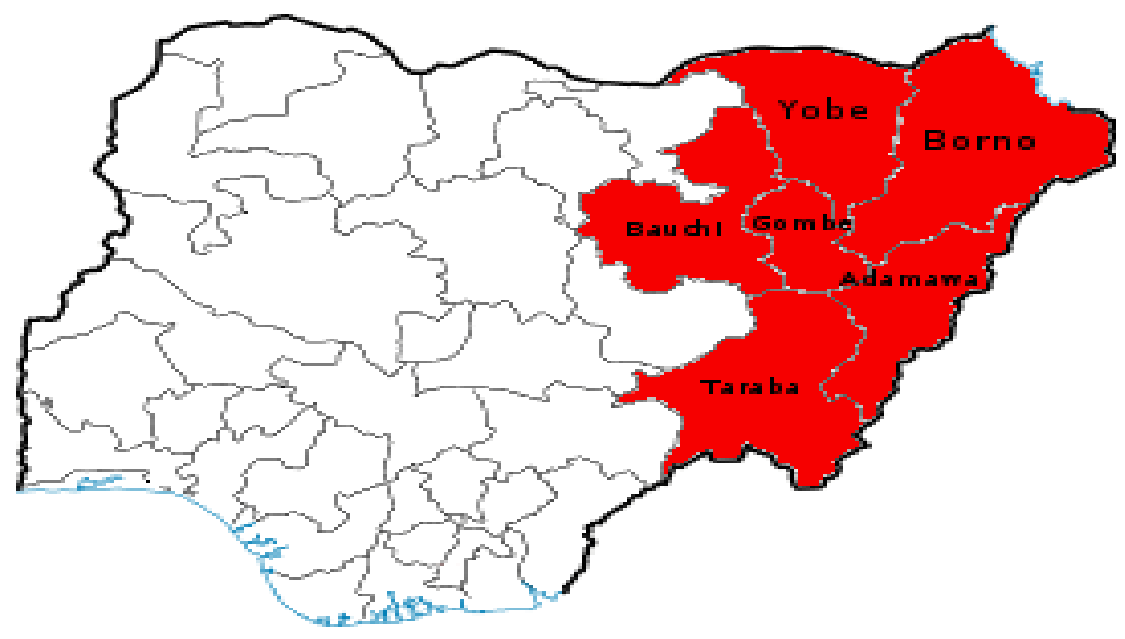

Source: Google Pictures 2018

Northeastern Nigeria comprises of approximately one-third of Nigeria's total area in square kilometre. The zone occupies $(280,419 \mathrm{~km} 2)$ of Nigeria's land area $(909,890 \mathrm{~km} 2)$ which is less than one-third but, more than one-fourth of 
the total area of the country. According to 2006 Population Census and its projection, Northeast has the population of $13.5 \%(23,558,674)$ of the Nigerian population which is put at 173, 905, 439 (National Bureau of Statistics, 2015).

The Northeast zone shares three international borders with Cameroon in the east, Chad in the Northeast and Niger Republic in the North. The geo-political zone is one of the major agricultural commodities producing areas that is supplying food to the country and its neighbouring states. The zone also has access to the famous Lake Chad Basin which is a good source of farming, fishing, transportation and livestock rearing. Unfortunately, the Northeast zone has the highest incidence of poverty in the country, low level of education and other indicators of living standard. The zone was peaceful for many periods with a longer history of religious activities, international trade through Trans-Sahara and mightier West African Kingdoms such as Kanem Bornu flourish historically in the zone for hundreds of years. Recently, the zone is affected by the Boko Haram insurgency which destabilised the zone and led to the establishment of many IDPs (NBS 2017).

\subsubsection{The Boko Haram Insurgency in Northeastern Nigeria}

Boko Haram is established in Northeastern Nigeria because of fundamentalism from some misguided miscreants which was assisted by the Nigerian environment as a reminiscent of the historical antecedents of misgovernance and extreme scorch of poverty (Campbell, 2014). Boko Haram is a radical Islamic preaching movement which later became a militant movement and a full-blown insurgency in the Northeastern states. The movement also affected Northwestern states of Kaduna and Kano and Northcentral state of Plateau and the Federal Capital Territory in Abuja. The group officially pronounced itself as 'Jama'atu Ahlul Sunnah Lid Da'awati Wal Jihad' translated in English as 'People committed to the propagation of the Prophet's teachings and Jihad'. The group secured the name 'Boko Haram' in Hausa language being the lingua franca in Northeastern Nigeria meaning 'Western education is prohibited' because of its critical pronouncement of disenchantment with the Western educational system (Bowser and Sanders, 2012 and Ahokegh, 2013).

\subsubsection{Genesis of Boko Haram insurgency in Northeastern Nigeria}

The original time and nature in which the Boko Haram insurgency started or emerged is disputable by many works. For instance, while most works suggested that the group emerged in 2009 with the famous clash that cost the life of their leader Muhammad Yusuf, one view emphasised that the group started as early as 1995 under the leadership of one called Malam Abubakar Lawal. The group from then on underwent series of names several times from Ahlul Sunnah Wal Jama'ah Hijra to the Nigerian Taliban to Yusufiyyah sect to Boko Haram. It is believed that the first attack from the group surfaced in 2003 in Kanama and Geidam in Yobe State in the Northeast and in 2005 in Panshekara in the Northwestern Kano State (Onuoha, 2010:55).

The Boko Haram has been given divergent perspectives and perceptions by researchers. It is considered as a political revolution, a religious fundamentalism, a social movement and a criminal activity. The activities of the sect transformed from insurgency in 2003 after the so-called Taliban attack in 2003 to terror activities from 2009 when the leader of the sect, Muhammad Yusuf was extrajudicially killed by the operatives of Police security in Borno. The group began attacking Police stations, army roadblocks and barracks and public gatherings with sophisticated guns and suicide bombings (De Montclos, 2014:137).

Other views supported the fact the group Boko Haram was established by its first leader, Muhammad Yusuf in 2002 in Maiduguri. From its inception in 2002, according to this view, the sect underwent various transformations, reorganisations and changes in its activities and approaches (Giroux \& Gilpin, 2014:2, Sergie \& Johnson 2014). A synthesising view was presented by Nkechi (2013) who argued that there are contradictions in the genesis of the Boko Haram sect and the best position to take here is to agree that there is no exact document or evidence of the original founder, date and activities of the Boko Haram sect. this work also adopted this position.

The Boko Haram group is believed by another author (Olojo, 2013:2) to have been established by one Abubakar Lawan in 1995 but, he secured admission in University of Madina and thus, appointed the late Muhammad Yusuf to be his successor before he returned. Boko Haram was originally a peaceful Islamic movement calling on its followers and the public to revert to pure teaching of Islam and to detest anything Western in nature. However, the group turned into a radical movement with the extrajudicial killings of Muhammad Yusuf in 2009. The group metamorphosed into an insurgency attacking different groups and targets in Nigeria involving Christians, Muslims, Nigerians, foreigners, troops, civilians, northerners and residents in the north. Their activities graduated into international borders of Niger Republic, Cameroon and Chad which led to a concern by the international community (Barna, 2014:1, Cook 2014:4 and Forest, 2012:3).

The group was given a new dimension by its new leader Abubakar Shekau who became the successor of the late Muhammad Yusuf on July 10th of 2009. He stressed that Jihad has started and within a short period of a time, the group emerged as the most violent in Africa because of its activities (Zenn, 2012 and Umar, 2013:1). Perhaps, Boko Haram differs with Maitatsine because it has modern sophisticated weapons and its attacks became wider in target than Maitatsine (Blanchard, 2014, Rogers, 2012, Montclos, 2014:8 and El Khaim, 2012:1). 


\subsubsection{Causes of Boko Haram Insurgency in Northeastern Nigeria}

There are divergent views on the causes of Boko Haram in Northeastern Nigeria but, the narration from the sects is what is questionable and much difficult to accept. The sect believed that their movement was anchored on the threshold of the command of the Holy Quran and Prophetic teaching which called for pure Islamic practices by the Muslim. But, all the verses of the Quran and Prophetic Hadith that they are quoting to justify their devilish act have been debunked by Islamic clerics as misinterpreted and misapplied by the misguided extremist. For example, Al Qardawi (1991:20) stressed that there is no compulsion in Islam and there is no provision on extremism and that, the modern terrors in the name of Islam and other religions are doing so based on their misperceptions, misguidance and misinterpretation of the text of the Quran and Prophetic Hadiths.

One of the major causes of Boko Haram insurgency in Northeastern Nigeria is identified as poor socioeconomic condition, poverty, ignorance and religious misperceptions (Forest, 2012, Chukwuma, 2014). Misgovernance is perceived as the main cause of the Boko Haram insurgency and the nature of Nigerian porous borders which allowed for illegal smuggling of weapons and exit escape route for the insurgents easily (Ahokegh, 2014 and Bamidele, 2012). Cook (2014) identified some major causes of Boko Haram insurgency to include rampant poverty in the North, Islamic fundamentalism, peculiarity of Kanuri tribe, African guerilla movement and climate change which desecrated the Sahel. The emergence of Boko Haram insurgency signifies grievances over misgovernance and sharp inequality in Nigerian society and a symptom of decades of failed government and elite delinquency finally ripening into social chaos (Sergie \& Johnson, 2014).

Other factors that necessitated the emergence of Boko Haram in the Northeastern Nigeria are poor security intelligence, deep-rooted corruption from public officials and military officers, unemployment, religious intolerance and misperception, ethnoreligious crises, elite rivalry, inequality and ignorance (Nkechi, 2013). The September 11 and Al Qaeda movement are another main cause of Boko Haram because the sect later recognised with Al Qaeda in the Maghrib (AQIM) (Olojo, 2013).

The issue of poor governance, corruption and socioeconomic woes in the North created the chasm for the emergence of insecurity in the Northeastern Nigeria (Barna 2014 and Meagher, 2014:1). Ideology and state failure in proffering measures of countering militant groups in the country such as the Niger-Delta militants paved the way for the emergence of other militants' groups such as Boko Haram in Nigeria (Isah, 2011:338). Another scholar added that the dichotomy in educational level and income inequality between the North and the South followed by sharp poverty, inequality and social injustice are what led to the root causes of Boko Haram movement in the North (Umar, 2013, Rogers, 2012 and De Montclos, 2014:8).

\subsubsection{Manifestations of Boko Haram Insurgency in Northeastern Nigeria}

Boko Haram insurgency started gradually in 2003 in Yobe State and in 2005 in Kano State. The violence became fully manifested in 2009 when the sect came out enmasse with heavy and sophisticated weapons to fight the security agency in Borno State. The attacks reached their peak in 2013 when the sect began attacking military bases and capturing local governments to the extent that they took over the control of 20 local governments by the end of 2013 in Borno, Yobe and Adamawa states.

From the year 2002 to 2018 , there were recorded more than fifty heavy attacks which claimed hundreds of lives and billions of Naira worth of value in properties and goods in the Northeast. Between the same period, there were more than ten recorded heavy attacks in the Northwest and Northcentral state of Plateau and Abuja (CNN Library 2018). These attacks were the major ones only because the total number of attacks from the Boko Haram insurgents could not be ascertained by any records since sometimes, they attack simultaneously in various parts of the Northeast and Northwest in the same day.

\subsubsection{Impact of Boko Haram Insurgency in Northeastern Nigeria}

One of the impacts of the Boko Haram insurgency in Northeastern Nigeria is the destruction of thousands of lives and properties worth billions of Naira in addition to stalling economic and commercial activities in the region for many years (Ahokegh, 2013). The Boko Haram insurgency in the Northeast led to the undermining of national security and it led to lack of public confidence in the security of their lives and properties (Bamidele, 2012). The effects of Boko Haram insurgency are that it created a negative international image for Nigeria and it led to campaign of calumny and misperception of Islam from different quarters where some misguided and sentimental commentators, academicians and analysts in addition to national media linked Islam directly with Boko Haram terrorism (Aro, 2013).

The Boko Haram insurgency created food scarcity in the Northeast, Nigeria and West Africa because more than half of the farmers in the region escaped with their lives and they have been living in IDPs camps for many years without cultivation and other farming activities (Olojo, 2013). The insurgency led to collateral damage in the Northeast accruing from the operation of the military personnel in the areas that are affected in which sometimes they killed innocent souls in the course of their operation (Omotosho, 2015) and it has been established that the emergence of Boko Haram insurgency disclosed the indelible failure of Nigerian government, sharp inequality, extreme poverty, corruption and misgovernance as well as division among Nigerian component groups (El Kaim, 2012). 


\subsubsection{The Response of the Nigerian Government and the International Community}

There are responses from the Nigerian government and international community towards the menace OF Boko Haram insurgency in Northeastern Nigeria but, the phenomenon continued, and this is the major concern of this work to identify the challenges that impedes the war from coming to an end. The Nigerian government responded with strategic military operation in the area conventionally as observed by (Onuoha 2010, Sulaiman 2014, Umar 2013 and Meagher 2014). The international community responded by helping with intelligence information, equipment, logistics and military support too as disclosed by (Serrano \& Pieri 2013, Giroux \& Gilpin 2014, Barna 2014, Meagher 2014, Blanchard 2014 and De Montclos 2014). However, both the Nigerian and international responses could not contain the insurgency appropriately which means there are certain challenges that are existing which prevent the success of the fight against insurgency and this is the main research gap identified by this work and its contribution to knowledge because all the works reviewed so far could not pay adequate attention to this aspect.

\section{Method of Data Collection and Analysis}

The work used an approach of qualitative data collection and analysis. qualitative data analysis is a research design that is used to collect a large group of data from a few data or informants given emphasis on the reliability and validity of the information and its quality in application. This is determined from the topic and subject matter of study (Bogden \& Biklen, 2007). The research is a phenomenological qualitative approach which examined the phenomenon of Boko Haram insurgency in the Northeastern Nigeria (Creswell, 2014:7). In a qualitative paradigm, both primary and secondary data is used where applicable as in the case of this study which deems it fit to use both for data collection and analysis (Sekaran \& Bougie, 2013 and Lune \& Berg, 2013).

For this work, the primary source of data is the use of an in-depth personal interview with some selected informants from the relevant actors. The informants that were selected are from five categories. Category one is six informants from the senior security officials from Nigerian security one from the Army, one from the Police, one from the Department of State Security Services (DSS), one from the Nigerian Security and Civil Defense Corps (NSCDC), one from the Nigerian Immigration Services (NIS) and one from the Nigerian Custom Services (NCS). Category B is four informants from senior officials in the Nigerian policymakers including a security adviser to the President, senior official in the Nigerian Institute for Policy and Strategic Studies (NIPSS), an officer in the Ministry of Defense in Abuja and another senior official in the Borno State civil service. Category 3 is academicians where three reputable Professors were selected for the interview; one from the Department of Political Science in Bayero University Kano, one from the Department of Sociology in University of Maiduguri and another from the Department of Geography in University of Maiduguri. The fourth category is the repented insurgents in which six of them were selected and interviewed in their rehabilitation camp in Gombe State. This is because it is not possible to access the insurgents because of the risk factors involved. The last category is the media men in which four journalists from reputable electronic and printed media across the Northeast were selected for the interview. In total, 23 informants were selected from five categories. The justification for this number is the suggestion by Creswell (2014) and Sharan (2009) that in a qualitative research, a minimum number of 8 informants and a maximum number of 30 informants can be selected for the interview depending on accessibility, quality of information, time framework and the nature of the research as well as the area of the study.

The secondary sources include books, journals, maps, internet sources and documented materials from international agencies and institutions. The data obtained from the field especially primary data were grouped and coded according to categorisation. The data were discussed and analysed using themes and sub-themes where applicable.

\section{Discussions and Findings : The Challenges of the Fight Against Insurgency in Northeastern Nigeria}

In this section, the information obtained from the field especially the informants' views were presented and analysed in themes using the existing literature and the application of the theoretical framework. The themes are discussed below.

\subsection{Corruption}

Corruption is the most permeative and social problem that is affecting the entire sectors of Nigeria not only the security. It has been observed that corruption exists among the top-ranking security personnel, bureaucrats and politicians in the fight against insurgency (Sule, Azizuddin \& Mat, 2017). Many top-ranking military officers were discovered to have been involved in the corrupt practices involving the money earmarked for fighting the insurgency in the Northeast. For instance, an amount worth $\$ 2.1$ billion (approximately 1 trillion Naira) allocated for the procurement of weapons to address insurgency was diverted for the PDP Presidential campaign in the 2015 General Election through the office of the National Security Adviser Rtd Colonel Sambo Dasuki (EFCC, 2017 and Sule, Azizuddin \& Mat, 2018). There are many corruption allegations on the security personnel in the fight against insurgency.

Most of the informants interviewed revealed that there is massive corruption in the fight against insurgency in the Northeast. Their summarised views disclosed that the military, bureaucrats in Abuja, politicians and the public are all 
involved in the corruption allegations which bedeviled the strive towards success in the fight against insurgency. They agreed that security personnel mounted checkpoints all over the Northeastern states but, they use to collect tokens of N20, N50 and N100 to allow vehicles to pass easily through the checkpoints without any thorough investigation. In this process, sophisticated weapons passed through the roads and reached the insurgents for their criminal activities. These views are supported by many scholars such as De Montclos (2014), Harvard Divinity Project (2018), Umar (2013), Sulaiman (2014) and Omotosho (2015).

\subsection{Porous Borders}

Nigeria is one of the countries in the world with a large geographical size, different climatic terrain and a porous border particularly in the North where it has the largest size with neighbourhood of more than four countries. Nigeria's land area $(909,890 \mathrm{~km} 2)$ is one of the biggest in the world. For instance, Cameroon shares the largest border with Nigeria in the North and the South of about 1, 680 kilometres, Nigeria's border with Nigeria's 1, 497 kilometre and the size of the border with Chad is 87 kilometre. These are the three countries that share the border and insurgency conflict with Nigeria and most of these borders are porous where there are entry and exit points uncountable (https://oldnaija.com/2015/12/07/boundaries-borders-of-nigeria/).

The insurgents have easy route to stage their criminal activities and escape without being traced. The Sambisa forest has a total size of 60 kilometres and this is the place where the insurgents hide and commit their crimes untraced (https://oldnaija.com/2015/12/07/boundaries-borders-of-nigeria/). The nature of Nigerian porous is identified by many scholars (El Kaim 2012, De Montclos 2014, Campbell 2014 and Ahokegh 2013) as one of the reasons why the fight against Boko Haram is challenging and continuous.

In the summary of the views of the informants, most of them or almost all of them agreed that the nature of Nigerian porous border is one of the challenging factors that prevent the fight against insurgency to succeed accordingly in the Northeast. They believed that the borders served as the main source of weapons, logistics, escape routes and other hiding places for the insurgents.

\subsection{Lack of Synergy Among the Affected Countries}

The countries that are affected by the insurgency; Nigeria, Cameroon, Niger Republic and Chad lack the synergy to coordinate and address the issue of insurgency which resulted in giving the insurgents the upper hand to move freely from one country to another to stage their attacks. The three countries of Cameroon, Chad and Niger Republic are Francophone countries under the mentorship of France while Nigeria is under the Commonwealth of British. This difference in external support, ideology, history, culture and the weakness of these countries being some of the poorest in the world led to lack of synergy among them to device a better means of fighting insurgency in the sub-region. This position has been supported by many scholars (Onuoha 2010, Barna 2014, Cook 2014, Sergie \& Johnson 2014 and Blanchard 2014).

In divergent views of the informants, they all agreed that lack of coordination among the countries that are affected is a major challenge that prolonged the insurgency in Northeastern Nigeria. They agreed that the differences in culture, language, external linkage of Anglophone and Francophone dichotomy and other challenges are serious issues that impeded the success of the war against terrorism in the Northeast and other affected areas.

\subsection{Absence of Cooperation Among the Security Personnel and Agencies}

It is noticed that there is no cooperation and support among the security personnel and this is one of the challenges that led to the prolonging of the fight against insurgency in Northeastern Nigeria. There are tensions, rivalries, hostilities and discord among them especially the military, police and DSS. This has been reported severally. The joint operation by these security agencies often ended in fiasco being defeated severally by the Boko Haram insurgents for them later to engage in trading words of blame among them. This is because of the failure to coordinate and design a strategic and tactical designation of responsibilities and operations among them. This has been observed by many scholars examined in this work such as Forest (2012), Zenn (2012), Rogers (2012) and Bamidele (2012).

Similarly, most of the informants agreed that the fight against insurgency in Northeastern Nigeria is facing the challenge of lack of cooperation among the security personnel. In their summarised views, they narrated that the challenge that the fight against insurgency in Northeastern Nigeria is facing is lack of full cooperation among the security personnel in the strategic level and in the field. The insurgents are better organised and coordinated than the Nigerian security agencies because they have their attacks coordinated and successful where the counter-attacks or offensive from the government's security failed many times.

\subsection{Hostilities from the Host Communities}

One of the challenging issues that is harmful to the success of the war against insurgency in Northeastern Nigeria is hostilities and suspicions between the host communities and the security agencies that are operating in the areas affected by the insurgents' activities. For instance, the security agencies blamed and suspect the host communities of 
withholding vital information that will lead to the success of their operation. They also suspect the host communities of shielding the insurgents. (Meagher 2014 and Sulaiman 2014).

The informants too revealed related information with the above views. Most of them narrated that there is a mutual suspicion between the security personnel and the host communities. They agreed that the host communities sometimes do not cooperate with the security agencies in giving relevant information that will lead to the success of the fight against the insurgents. On the other hand, the informants believed that the military torture and suffer the host communities especially the innocent souls and this is why they sometimes cooperate more with the insurgents than with the security personnel.

\subsection{Low Motivation of the Security Personnel}

It is recorded officially that the security personnel are not motivated in the fight against insurgency and this has led to low morale and lack of motivation to fight. In most cases, the weapons given to them is below that of the insurgents, their allowances were delayed and not paid in full and sometimes it was not paid at all, when an officer sustained a serious injury, he is allowed to be catered by his family instead of the government that he is serving. Many scholars (Isah 2011, Aro 2013, Serrano \& Pieri 2013, Sulaiman 2014 and Sule, Sambo \& Tal, 2018) all submitted in agreement to this view.

All the informants contacted especially the ones from the security agencies accepted this notion that the security is not motivated to adequately boost their morale to fight the insurgency in Northeastern Nigeria. They narrated that the security personnel who laid down their lives at the highest risk of being killed by the insurgents abandoned their family and relatives to serve their country but, unfortunately, they were not paid even their salaries on time, their allowances were unnecessarily slashed, medical services were terrible for the injured officers in the field and their weapons are inferior to that of the insurgents.

\subsection{Poor Logistics and Techniques}

One of the major challenges that affects the success of the fight against insurgency is poor logistics and techniques. The security personnel are not given enough weapons to confront the insurgents, their mode of transportation made them vulnerable to guerilla attacks from the insurgents, intelligence level is very low and intelligence gathering was poor. All these impede the success of the fight against insurgency as observed by De Montclos (2014), Sulaiman (2014), Forest (2012) and Aro (2013). Furthermore, all the interviewers from all the five categories agreed unanimously that the fight against insurgency in Northeastern Nigeria is not successful because of the challenge of poor logistics that made the security personnel vulnerable and expose to the dangers of being overwhelmed by the insurgents who appeared better organised and logistically more coordinated than the Nigerian security.

\subsection{Politicisation of the War Against Insurgency in Northeastern Nigeria}

The war against insurgency in the Northeastern Nigeria has been politicised for many years. The government presented false information and figures in the warfront. Sometimes the government and the security personnel will debunk the number of casualties either killed by the Boko Haram insurgents or the security agencies themselves with conflicting figures. On the other hand, the government and the security personnel will announce sometimes that they succeeded in capturing top Boko Haram commanders or killing them which later proved to be untrue as the said killed commanders will appear in a video clip to establish their existence. This occurred severally in many towns in the Northeast as indicated by Forest (2012), Nkechi (2013), Cook (2014) and Giroux \& Gilpin (2014).

Most of the informants or almost all of them in all the categories interviewed agreed that the Nigerian has politicised the war against insurgency by claiming that it has succeed where it has not. For instance, some of the interviewers lamented that, we are all aware that the government claimed to have killed Abubakar Shekau, the Boko Haram leader more than ten times but, unfortunately, he will always appear in a video clip to debunk the claim and reassert his declaration of fighting the government. This is politicisation of the issues.

\section{Conclusion and Recommendation}

The study concludes that the Boko Haram insurgency started as a peaceful but, rather a radical preaching session to debunk anything Western in the Muslim society in Nigeria but, it later turned into a radical movement because of the perceived extrajudicial killing of the sect leader Muhammad Yusuf. The study concludes that Boko Haram insurgency has devastating effects on the Northeastern population and the environment at large. The study concludes that there are challenges which prevent the success of the fight against insurgency in Northeastern Nigeria which were discussed in detail as revealed by many informants interviewed in the research. The study recommends the following as the lasting solutions to bring the phenomenon of insurgency to its logical end:

1. There is need for the government and the security personnel to give much emphasis on intelligence gathering to have a superior and advanced information that will lead to easy defeat of the insurgents; 
2. Better and sophisticated modern warfare equipment should be procured to boost the morale of the combatants to defeat the insurgents in the conventional fight;

3. The harmony should be established between the host communities and the security operatives that operate in the areas that are affected by the insurgency by appointing the local from the host communities who will serve as insiders; 4. The Sahel states that are affected by the insurgents should indulge the assistance of the ECOWAS, AU and the UN in the provision of logistics and support;

5. The government should avoid playing politics with the issue of insurgency and reveal the real situation on ground to keep the public alerted because this will help in saving lives and properties;

6. There is a need for motivating the security personnel by giving them their entitlements all of them promptly and adequately;

7. All religious radical movements and other militants' groups in the country should be dealt with justly and their proliferation should be prevented in future;

8. The government should pay much attention to socioeconomic issues that make the life of the common man miserable in the country by providing jobs, eradication of poverty and other sound economic policies that can engage the teeming restive idle youth in productive ventures to prevent them from falling preys against evil machinations of fundamentalist groups and

9. There is need for a collective responsibility from all the countries that are affected by the insurgency to address the issue of insurgency in the Sahel states of West Africa.

\section{References}

Ahokegh, A.F. (2013) “Boko Haram: A 21st Century Challenge in Nigeria” European Scientific Journal. 8(21): 46-55

Aro, O.I. (2013) "Boko Haram Insurgency in Nigeria: Its Implication and Way Forward Towards Avoidance of Future Insurgency in Nigeria" International Journal of Scientific and Research Publication. 3(11): 178-185.

Bamidele, O. (2012) "Boko Haram Catastrophic Terrorism-An Albatross to National Peace, Security and Sustainable Development in Nigeria” Journal of Sustainable Development in Africa. 14(1): 32-44.

Barna, J. (2014) Insecurity in Context: The Rise of Boko Haram in Nigeria. European Parliament: Directorate-General for External Policies.

Blanchard, L.P. (2014) Nigeria’s Boko Haram: Frequently Asked Questions. Congressional Research Service.

Bowser, E.F. \& Sanders, A. (2012) Security Threats in the Sahel and Beyond: AQIM, Boko Haram and Al-Shabab. Civil-Military Fusion Centre; Mediterranean Basin Team.

Campbell, J. (2014) Boko Haram: Origins, Challenges and Responses. NOREF: Norwegian Peacebuilding Resource Centre.

CNN Library (2018). Retrieved from https://avarchivingjobs.wordpress.com/2016/10/30/cnn-library-internship-2positions-spring-2017-cnn-atlanta-ga/

Cook, D. (2014) Boko Haram: A New Islamic State in Nigeria. James A. Baker III Institute for Public Policy, Rice University.

Creswell, J.W. (2014) Research Design: Qualitative, Quantitative \& Mixed Methods Approaches. California: Sage Publication.

De Montclos, M.A.P. (2014) Nigeria’s Interminable Insurgency: Addressing the Boko Haram Crisis. London: Chatham House.

De Montclos, M.A.P. (2014) "Boko Haram and Politics: from Insurgency to Terrorism" in De Montclos (ed) Boko Haram: Islamism, Politics, Security and the State in Nigeria. African Studies Centre.

Economic and Financial Crimes Commission (2017). Report on the Investigation of the Dasuki Arms Scandal. Retrieved from www.efcc.org.

El Kaim, Z. (2012) Boko Haram: The Rise, Success and Continued Efficacy of The Insurgency in Nigeria. Herzliya: International Centre for Counter-Terrorism. 
Forest, J.J.F. (2012) Confronting the Terrorism of Boko Haram in Nigeria. Florida: The JSOU Press.

Giroux, J. \& Gilpin, R. (2014) Nigeria on the Edge. Zurich: Policy Perspectives.

Google Pictures (2018) Retrieved from https://services.srchweb.org/search/map\%20/northeast

Harvard Divinity Project (2018) The Maitatsine Riots. Religious Literacy Project. https://oldnaija.com/2015/12/07/boundaries-borders-of-nigeria/

Isah, M.K. (2011) "Militant Islamist Groups in Northern Nigeria” in Okumu, W. \& Ikelegbe, A. (Eds) Militias, Rebels and Islamist Militants: Human Insecurity and State Crises in Africa. South Africa: Institute for Security Studies.

Lune, H \& Berg, L. (2017) Qualitative Research Methods for the Social Sciences. Edinburgh: Pearson Education Limited.

Meagher, K. (2014) Beyond Terror: Addressing the Boko Haram Challenge in Nigeria. NOREF: Norwegian Peacebuilding Resource Centre.

National Bureau of Statistics (2017) Population of Nigeria. Retrieved from www.nbs.org.

Nkechi, O.A. (2013) "Boko Haram and National Security Challenges in Nigeria: Causes and Solutions" Journal of Economics and Sustainable Development 4(5): 12-23.

Olojo, A. (2013) Nigeria's Troubled North: Interrogating the Drivers of Public Support for Boko Haram. The Hague: International Centre for Counter-Terrorism.

Omotosho, M. (2015) "Dynamics of Religious Fundamentalism: A Survey of Boko Haram Insurgency in Northern Nigeria" Journal of Philosophy, Culture and Religion 4:8-15.

Onuoha, F.C. (2010) Small Arms and Light Weapon Proliferation and Human Security in Nigeria. ConflictTrends.

Rogers, P. (2012) Nigeria: The Generic Context of Boko Haram. Oxford Research Group.

Sekaran, U. \& Bougie, R. (2013) Research Methods for Business. India: John Wiley \&Sons.

Sergie, M.A. \& Johnson, T. (2014) Nigeria’s Boko Haram and Ansaru. Council on Foreign Relations

Serrano, R. \& Pieri, Z. (2013) "By the Numbers: The Nigerian State Efforts to Counter Boko Haram" in De Montclos (ed) Boko Haram: Islamism, Politics, Security and the State in Nigeria. African Studies Centre.

Sharan, M.P. (2009) Qualitative Research Method San Francisco: John Wiley \& Sons.

Sulaiman, M.D. (2014) “Centenary of Failure? Boko Haram, Jihad and the Nigerian Reality” ARAS 35(2): 69-86.

Sule B, Azizuddin M, Sani M, Mat B (2017) Political Party Financing and Corruption in Nigeria's Fourth Republic: The Case of 2015 General Elections. Arts Social Sci J 8: 298.

Sule, B. Azizuddin, M. Sani, M. Mat, B. (2018) Corruption and Electoral Process in Nigeria: Examining the 2015 General Elections in Journal of Technosocial. 10(1), 1-16.

Sule, B. Sambo, U. \& Tal, M.K. (2018) Islamic Militants and Insurgency in Northeastern Nigeria: A Comparison of the Ideology and Methodology of Maitatsine and Boko Haram. Journal of Academia. 7(2), 76-91.

Umar, A.M. (2013) "Nigeria and The Boko Haram Sect: Adopting a Better Strategy for Resolving The Crises" Maters Thesis: Naval Postgraduate School Monterey, California.

Zenn, J. (2012) "Boko Haram Dangerous Expansion into Northwest Nigeria” Combating Terrorism Centre at West Point (CTC Sentinel) 5(10):1-6. 